\title{
Economic Analyze of Costs and Return of Fish Farming in Saki-East Local Government Area of Oyo State, Nigeria
}

\author{
Adeniyi Bashir Tunde ${ }^{1 *}$, Kuton MP², Ayegbokiki Adedayo Oladipo ${ }^{3}$ and Lawal Hakeem Olasunkanmi ${ }^{4}$ \\ ${ }^{1}$ Aquaculture and Fisheries Research Programme, Institute of Food Security, Environmental Resources and Agricultural Research (IFSERAR), Federal University of \\ Agriculture, Abeokuta, Nigeria \\ ${ }^{2}$ Department of Marine Sciences, University of Lagos, Akoka, Lagos, Nigeria \\ ${ }^{3}$ Food Security and Socio-Economic Research Programme, Institute of Food Security, Environmental Resources and Agricultural Research (IFSERAR), Federal University \\ of Agriculture, Abeokuta, Nigeria \\ ${ }^{4}$ Department of Agricultural Economics and Farm Management, Federal University of Agriculture, Abeokuta, Nigeria
}

\begin{abstract}
Aquaculture is regarded as a lucrative and important endeavour in terms of income generation and supply of animal protein to the majority of population in the country. The study examined economic analysis of fish farming in Saki-East Local Government Area (LGA) of Oyo State, Nigeria. Structured questionnaire was administered to randomly selected respondents to represent the fish farming community in the study area. Data collected were analyzed using descriptive statistics, costs and budgetary analysis and multiple regression analysis.

The results of a Cost and Return Analysis of the fish farming in the study area showed that the total revenues was $\mathrm{N} 244364.30 \mathrm{k}$ per cycle, whereas total cost was $\mathrm{N} 129379.52 \mathrm{k}$ per cycle. This implies that fish farming was profitable and is expected to continue to operate. In addition, Benefit Cost Ratio (BCR) was 1.9, the fish farming is therefore considered to be profitable. The rate of Return on Investment was 0.8887 , meaning, for every N1 invested; there will be a return of $88.8 \mathrm{k}$.
\end{abstract}

Keywords: Economic analysis; Fish production; Revenue; Total cost; Profitability

\section{Introduction}

Aquaculture is the practice of rearing, growing or producing products in water or in managed water systems. Products of aquaculture include plants, insects, crustaceans, bivalves and pearls, fish, and anything else grown in water. Mires, also defined aquaculture as the commercial rearing of fish in conditions where all the basic means of production can be controlled within their respective limitations and from which producers aim to obtain optimal economical results.

Fish farming, an aquaculture practice, which involves the raising of fish, has a long history. Fish were raised in ponds in the ancient civilizations of Egypt and Mesopotamia around 3000BC and carp have been reared in china since about 2000BC. During the middle Ages in Europe, fish ponds were of great important for the supply of fresh during lent and of fast days, and fish farming was generally associated with the monasteries. Fish farming almost disappeared in England after the reformation and in Germany during the thirty years war. However, there was a considerable revival in Germany and central and Eastern Europe during the last century.

Today China is by far the most important producer of farmed fish, accounting for over half the total world output. Aquaculture was introduced to Nigeria in the late 1930's and early 1940s, with the first fish pond built around Onikan, Lagos in 1941. The trend of development followed the same pattern as in other African countries, which have not been very encouraging. According to Fagade [1] in spite of the fact that over 1.5 million hectares of surface water area is available for fish culture, no appreciable result has been recorded in the culture sub-sector.

Fishing like other hunting activities has been a major source of food for the human race and has put an end to unsavoury outbreak of anaemia, Kwashiorkor and so on. Fish accounts for about one fifth of world total supply of animal protein and this has risen five folds over the last forty years from 20million metric tones to 98 million metric tones in 1993. According to Tobor stated that protein of animal origin is in short supply in Nigeria as increase in livestock population is being limited by several causes including virus diseases, drought, scarcity, and high cost of feeds and low genetic potential of indigenous livestock breeds. Short supply and increase in human population have the combined effect of raising the cost of animal protein to a level beyond the reach of low-income groups. The situation has given rise to considerable increase in the demand for fish to supplement animal protein. Also, [2] revealed that fish allows for protein improved nutrition in that it has a high biological value in terms of high protein retention in the body. Furthermore, Slang stated that fish has higher protein assimilation as compared to other animal protein sources, low cholesterol content and one of the safest sources of animal protein. Also, the FAO [3] revealed that West African Countries, of which Nigeria is one, obtain at least 50 percent of their animal protein needs from fish and fish products.

Moreover, Adekoya [4] stated that marine fish products account for at least 60 per cent of the non-plant protein consumed in Nigeria. According to Aromolaran and Akintunde, the residents of Warri in

${ }^{*}$ Corresponding author: Adeniyi Bashir Tunde, Aquaculture and Fisheries Research Programme, Institute of Food Security, Environmental Resources and Agricultural Research (IFSERAR), Federal University of Agriculture, Abeokuta Nigeria, Tel: 880-171-2141273; E-mail: adeniyibt@funaab.edu.ng

Received November 03, 2014; Accepted December 16, 2014; Published January 18, 2015

Citation: Tunde AB, Kuton MP, Oladipo AA, Olasunkanmi LH (2015) Economic Analyze of Costs and Return of Fish Farming in Saki-East Local Government Area of Oyo State, Nigeria. J Aquac Res Development 6: 306. doi:10.4172/21559546.1000306

Copyright: $(2015$ Tunde AB, et al. This is an open-access article distributed under the terms of the Creative Commons Attribution License, which permits unrestricted use, distribution, and reproduction in any medium, provided the original author and source are credited. 
Nigeria preferred fish and actually consumed it more frequently than any other animal protein source. The author found that the average household in the area consumed fish at least once a day for 16 days in one month.

In Nigeria, the population of fish is about 0.7 million metric tons annually which results in a shortfall of about 1.0 million metric tons annually. Only $5 \%$ of this 0.7 million metric tone produced locally is from aquaculture. The remaining $95 \%$ is from the capture fisheries, which are dominated by the artisanal fishermen. Out of 35 grams of animal protein per day per person recommended by food and agricultural organization, less than 7 grams is consumed on the average [5]. As a result of this, many Nigerians suffer from protein deficiency due to low protein intake.

\section{Economicimportance of aquaculture and fishery management in Nigeria}

1. It increases food production, especially of animal proteins, and achieving self-sufficiency in aquatic products supplies.

2. It contributes to improvement of human nutrition.

3. It generates new source of employment in rural areas, including part-time employment of farmers and small-scale fishermen, and arresting the migration of people from rural to urban areas.

4. Earning foreign exchange through export or saving foreign exchange through import substitution.

5. It promotes agro-industrial development, which could include processing and marketing of fishery products, feeds and equipment for aquaculture, and seaweed culture for the production of marine colloids, pearl oyster culture etc.

6. It creates and maintains leisure-time activities, including sport fishing and home and public aquaria.

7. Overall development of rural areas through integrated projects, including aquaculture.

\section{Aquaculture management system}

Fish farming may range from large scale industrial enterprises to 'backyard' subsistence ponds. Farming systems can be distinguished in terms of input levels.

1. Extensive system: In extensive fish farming, (economic) inputs are usually low. Natural food production plays a very important role, and ponds productivity is relatively low. Fertilizer may be used to increase pond fertility and thus fish production.

2. Semi-intensive system: a moderate level of inputs is used and fish production is increase by the use of fertilizer and/or supplementary feeding. This means higher labour and food costs but higher fish yields more than compensate for this usually.

3. Intensive system: a high level of inputs is used and the ponds are stocked with as many fish as possible. The fish are fed supplementary food, and natural food production play a minor role [6]. In this system, the high feeding costs and risks, due to high fish stocking densities and thus increased susceptibility to diseases and dissolved oxygen shortage, can become difficult management problems. Because of the high production costs you are forced to fetch a high market price in order to make the fish farming economically feasible.

\section{Problem statement}

Nigeria has become one of the largest importers of fish in the developing world, importing about 600,000 metric tons annually. To solve the country's problem of high net supply deficit for fish, Nigeria must turn to their under-utilized inland water for improved fish production and aquaculture. Aquaculture expansion, moreover, as been a slow process, as private sector fish farmers have faced major constraints, including lack of seed and quality feed, limited access to institutional credit, lack of skilled personnel as well as inadequate database on biological and ecological requirements of indigenous species with aquaculture potential [7].

Since fish is the most perishable among the good quality food protein sources and usually the cheapest source of animal protein. It is therefore necessary to utilize our limited scarce resources judiciously. In spite of the ever-increasing growth being witnessed by other major sources of animal protein such as livestock and poultry industries, this problem of protein deficiency has continued unabated. The need therefore arise, to explore aquaculture as a means of addressing the problem of protein inadequate protein intake in Nigeria.

\section{The study attempted to achieve the following objectives}

a. To describe the socio-demographic characteristics of fish farmers in the study area;

b. To determine the cost, profitability and viability of fish farming

c. To determine the factors influencing fish production on the study areas;

d. To make relevant recommendations based on the findings of the study.

\section{Methodology}

Saki-East local government was created alongside 182 others created by the federal government during General Sanni Abacha administration in December, 1996. The council was carved out of the defunct Ifedapo local government area. Saki-East comprises of five major towns namely: Agbonle, Ago-Amodu, Ogbooro, Oje-Owode, and Sepeteri. The zoological Old Oyo National Park is located in Sepeteri and the landmass is about $200 \mathrm{~km}^{2}$ while the terrain is undulating and paling Savannah grassland with dotted rocks and hills. The common trees are sheabutter and locust bean trees [8]. The local government council is bounded in the north by Oorelope local government, to the south by Atisbo and Olorunsogo to the East and Saki-West to the west. Saki-East local government covers a land area of $1,569 \mathrm{~km}^{2}$ and a population of 110,223 based on 2006 census [9].

\section{Method of data collection}

Saki-East local government was purposely selected as the study area based on the convenience and familiarity of the researchers to the environment; this was also done to reduce research cost [10]. Primary data were obtained through a random sampling of 50 active fish farmers across the five major towns of Saki-East local government namely: Agbonle, Ago-Amodu, Ogbooro, Oje-Owode, and Sepeteri using structured questionnaires on various aspects of fish farming such as socio-demographic characteristics of the farmer, production income and financial investment. Ten fish farmers were randomly selected in each of the five major towns in the study area.

\section{Analytical techniques}

To satisfy the objectives of the study, the following analytical tools 
were used:

a. Descriptive analysis such as frequency and percentage were used to describe socio-demographic characteristics of fish farmers.

b. Cost and returns analysis were used to examine the cost and returns of fish farming.

c. Profitability rations such as Benefit-Cost Ratio, Return on investment were used to analyze profitability and viability of fish farming.

$\mathrm{BCR}=\mathrm{TR} / \mathrm{TC}$

Where;

$\mathrm{BCR}=$ Benefit Cost Ratio

$\mathrm{TR}=$ Total Revenue

$\mathrm{TC}=$ Total Cost

Return on Investment $(\mathrm{ROI})=$ Profit $/$ Total Cost

d. Regression Techniques was employed to identify factors that influence fish production in the study area.

$\mathrm{Y}=\mathrm{f}(\mathrm{X} 1, \mathrm{X} 2, \mathrm{X} 3, \ldots \mathrm{X} 8, \mathrm{U})$

where:

$\mathrm{Y}=$ total value of production

$\mathrm{X} 1$ = age of farmers in years

$\mathrm{X} 2$ = size of pond $\left(\mathrm{m}^{2}\right)$

$\mathrm{X} 3=$ total fish seed (naira)

$\mathrm{X} 4=$ cost of feed (naira)

$\mathrm{X} 5=$ value of total fertilizer and lime input (naira)

$\mathrm{X} 6=$ value of total labour input (naira)

$\mathrm{X} 7$ = educational status of the farmers

$\mathrm{X} 8=$ sex of the farmers (Dummy: $1=$ male, $0=$ female)

$\mathrm{U}=$ error term assume to have a zero mean and constant variance.

The following functional forms were analyzed in order to choose the lead equation:

$\mathrm{Y}=\mathrm{b} 0+\mathrm{b} 1 \mathrm{X} 1+\mathrm{b} 2 \mathrm{X} 2+\mathrm{b} 3 \mathrm{X} 3+\mathrm{b} 4 \mathrm{X} 4+\mathrm{b} 5 \mathrm{X} 5+\mathrm{b} 6 \mathrm{X} 6+\mathrm{b} 7 \mathrm{X} 7+\mathrm{b} 8 \mathrm{X} 8$ (Linear form)

$\mathrm{Y}=\mathrm{b} 0+\ln \mathrm{b} 0+\mathrm{b} 1 \ln \mathrm{X} 1+\mathrm{b} 2 \ln \mathrm{X} 2+\mathrm{b} 3 \ln \mathrm{X} 3+\mathrm{b} 4 \ln \mathrm{X} 4+\mathrm{b} 5 \ln \mathrm{X} 5+$ $\mathrm{b} 6 \ln \mathrm{X} 6+\mathrm{b} 7 \ln \mathrm{X} 7+\mathrm{b} 8 \ln \mathrm{X} 8$

$\mathrm{LnY}=\mathrm{b} 0+\mathrm{b} 1 \ln \mathrm{X} 1+\mathrm{b} 2 \ln \mathrm{X} 2+\mathrm{b} 3 \ln \mathrm{X} 3+\mathrm{b} 4 \ln \mathrm{X} 4+\mathrm{b} 5 \ln \mathrm{X} 5+\mathrm{b} 6 \ln \mathrm{X} 6+\mathrm{b} 7$ $\ln \mathrm{X} 7+\mathrm{b} 8 \ln \mathrm{X} 8$ (Double Log)

\section{Results and Discussion}

\section{Socio-economic characteristics of the respondents}

The Table 1 below shows the socio-economic characteristics of respondents in the study area. The result showed that about 94 percent of the respondents were male while the female were just 3 , representing 6 percent of the respondents [11]. This is an indication that the production of fish is widely popular among the males in the study area while the women might likely be more involved in the marketing aspect of the enterprise.
The age distribution of the respondents showed that most of the fish farmers are still in their active youth age; hence, high productivity should be expected in the study area as about 36 percent and 30 percent of the respondents fall between the age range of 20-30 years and 31-40 years respectively.

The marital status of reflects that 38 respondents, representing about 76 percent were married while about 22 percent were still single. A negligible amount no of the respondents, representing about 2 percent was divorced.

As observed in the table below, the minimum household size of the respondent is 1 and the maximum been 15 people [12]. The observation shows that majority of the respondents (about 56 percent) have an average household size of between 1-5 while about 26 percent and 18 percent of the respondents have household size of between 6-10 and $11-15$ respectively.

The population of fish farmers with tertiary education is very high in Saki-East Local Government. 52 percent of the farmers have tertiary qualification while 20 percent have secondary education. The high level of education status recorded among the farmers might not be unconnected with the high percentage of civil servants among the respondents as about 32 percent are majorly civil servants who do fish farming as secondary occupation. Result showed that 34 percent of the respondents have fish farming as their major occupation [13]. Trading was also noticed to be the main occupation of some respondents (12 percent) in the study area while 22 percents of the respondents have various other jobs such tailoring, barbing, auto mechanic, etc., as their major occupation.

\section{Cost and return analysis}

The cost of various input used in fish production is described in Table 2 below. Gross return is the monetary value that fish farmers derive from fish catch (output), the gross return or total revenues from fish production in the study area was N244,363.30k per cycle, whereas total fixed costs were N39,773.79k, total variable cost was N89605.73k per cycle. The result showed a profit margin of N114984.78K per cycle. This implies that fish farming in Saki-East local government area is a profitable enterprise [14].

Benefit Cost Ratio (BCR) explains how much the owner gets from every N1 expended on the project. Fish farming in Saki-East LGA seems highly feasible since BCR recorded a value of 1.9 [15]. This result is similar to the work carried out by Ngazy titled 'Appraising Aquaculture of ZALA Park fish cultivation and Makoba Integrated Mariculture Pond System' in which the BCR was 1.5. The Return on Investment (ROI) showed a value of 0.888 which implies that for every N1 invested; there will be a return of 88.8 kobo.

\section{Factors influencing fish production in the study area}

Table 3 below summarized the regression results showing the parameters that are significance to fish production in the study area for the purpose of capturing objective number four. Estimated double log was chosen as the lead equation from the three functional forms based on the economic criteria (signs of the regression coefficient), statistical criteria (significance of $\mathrm{t}$-value) and the value of $\mathrm{R}^{2}$.

The results of double log production function models estimate showed six parameters to be positive compared to linear and semi $\log$ with five parameters each [16]. The result reveals that only quantity of feed, quantity of lime and respondents sex are significant 
Citation: Tunde AB, Kuton MP, Oladipo AA, Olasunkanmi LH (2015) Economic Analyze of Costs and Return of Fish Farming in Saki-East Local Government Area of Oyo State, Nigeria. J Aquac Res Development 6: 306. doi:10.4172/21559546.1000306

Page 4 of 5

\begin{tabular}{|c|c|c|}
\hline Variable & Frequency & Percentage \\
\hline \multicolumn{3}{|l|}{ Sex } \\
\hline Male & 47 & 94 \\
\hline Female & 3 & 6.0 \\
\hline Total & 50 & 100 \\
\hline \multicolumn{3}{|l|}{ Age (Years) } \\
\hline $20-30$ & 18 & 36.0 \\
\hline $31-40$ & 15 & 30.0 \\
\hline $41-50$ & 12 & 24.0 \\
\hline $51-60$ & 4 & 8.0 \\
\hline 60 and above & 1 & 2.0 \\
\hline Total & 50 & 100.0 \\
\hline \multicolumn{3}{|l|}{ Marital Status } \\
\hline Married & 38 & 76.0 \\
\hline Single & 11 & 22.0 \\
\hline Divorced & 1 & 2.0 \\
\hline Total & 50 & 100.0 \\
\hline \multicolumn{3}{|l|}{ Household size } \\
\hline $1-5$ & 28 & 56.0 \\
\hline $6-10$ & 13 & 26.0 \\
\hline $11-15$ & 9 & 18.0 \\
\hline Total & 50 & 100.0 \\
\hline \multicolumn{3}{|l|}{ Education status } \\
\hline No formal education & 3 & 6.0 \\
\hline Primary education & 11 & 22.0 \\
\hline Secondary education & 10 & 20.0 \\
\hline Tertiary education & 26 & 52.0 \\
\hline Total & 50 & 100 \\
\hline \multicolumn{3}{|l|}{ Primary occupation } \\
\hline Farming & 17 & 34.0 \\
\hline Trading & 6 & 12.0 \\
\hline Civil servant & 16 & 32.0 \\
\hline Artisan \& others & 11 & 22.0 \\
\hline Total & 50 & 100 \\
\hline
\end{tabular}

Source: Field Survey, 2013.

Table 1: Socio-economic characteristics of respondents in the study area

factors affecting fish farming output in Saki-East LGA at 5 percent level of significance. This implies that a percentage increase in these variables will lead to certain percentage increases in the dependent variable (total value of production) assuming all other factors are held constant. Parameters such as fish seeds, age and level of education of the respondents were found to be positive, indicating a positive increase with a unit increase in the factors, though not significant at any probability level. These factors also support the findings of Ahmed et al. [5] which concluded that stocking density and pond size are the factors that significantly influenced tilapia output in small water bodies in Bangladesh.

The F-value of 2.09 being significant is also an indicator that the model has a good fit to justify the factors influencing the fish farming operations in the study area. The values of parameter estimates of the double log equation showed an elasticity of production. The summation of the parameter estimates $(\mathrm{b} 1+\mathrm{b} 2+\ldots \mathrm{b} 8)$ gives a value of 3.961 indicating that farmers are operating in stage 1 of production function. This suggests that fish production in the study area had an increasing positive return to scale.

The explicit form of the lead equation is;

$\mathrm{Y}=0.18+0.082 \mathrm{X} 1-0.374 \mathrm{X} 2+0.318 \mathrm{X} 3+2.832 \mathrm{X} 4^{\star}-2.009 \mathrm{X} 5^{*}$ $0.302 \mathrm{X} 6+0.737 \mathrm{X} 7+2.677 \mathrm{X} 8^{*}+\mathrm{Ui}$
$(0.858)(0.935)$
$(0.711)$
$(0.752)$
$(0.04)$
$(0.041)$

$(0.764)$ $(0.466) \quad(0.05)$

$\mathrm{R}^{2}=17.5 \% \quad$ F-values $=2.09 \quad{ }^{*}$ coefficient significant at $5 \%$ level.

Out of all the eight explanatory variable captured in this study, only three (quantity of feed, X4; quantity of lime, X5; and sex, X8) were found significant at $5 \%$ level. This means that only these three variables exerted significant influence on the total revenue of fish produced in the study area. Quantity of feed (X4) showed a positive relationship with the total revenue, this implies that for every percentage increase in quantity of feed at a given level of other variable inputs will increase total value of production by $2.83 \%$. Quantity of lime (X5) showed a negative relationship with the level of income, which implies that

\begin{tabular}{|c|c|}
\hline ITEM & Total Values (A : K) \\
\hline Total Revenue & 244364.30 \\
\hline \multicolumn{2}{|c|}{ Fixed Cost } \\
\hline Drag Net & 26656.25 \\
\hline Water Pump & 1740.08 \\
\hline Weighing Scale & 2147.86 \\
\hline Knives/Cutlasses & 1576.42 \\
\hline Other Fixed Input & 638.89 \\
\hline Total Fixed Costs (TFC) & 7014.29 \\
\hline & 39773.79 \\
\hline Labour & 19335.02 \\
\hline Fingerlings (Catfish) & 32503.40 \\
\hline Fingerlings (Tilapia) & 1144.34 \\
\hline Poultry Dung (kg) & 9905.71 \\
\hline Maggot (kg) & 1050.11 \\
\hline Concentration Diet (kg) & 10445.95 \\
\hline Other Feeds (kg) & 2801.11 \\
\hline Limes & 12420.09 \\
\hline Total Variable Costs (TVC) & 89605.73 \\
\hline Total Cost (TFC+TVC) & 129379.52 \\
\hline Net profit (1-2) & 114984.78 \\
\hline Return on Investment (ROI) & 1.9 \\
\hline Befit-Cost Ratio (BCR) & 0.8887 \\
\hline
\end{tabular}

Source: Field survey cost analysis.

Table 2: Cost and return analysis of fish production in saki-east local government 
Citation: Tunde AB, Kuton MP, Oladipo AA, Olasunkanmi LH (2015) Economic Analyze of Costs and Return of Fish Farming in Saki-East Local Government Area of Oyo State, Nigeria. J Aquac Res Development 6: 306. doi:10.4172/21559546.1000306

Page 5 of 5

\begin{tabular}{|c|c|c|c|c|c|c|c|c|c|c|c|c|}
\hline \multicolumn{13}{|c|}{ Linear } \\
\hline Constant & $b_{1}$ & $b_{2}$ & $b_{3}$ & $b_{4}$ & $b_{5}$ & $b_{6}$ & $b_{7}$ & $b_{8}$ & $\mathbf{R}^{2}$ & $\overline{\mathbf{R}}^{2}$ & $\mathbf{F}$ & Sig. \\
\hline-0.044 & 0.420 & -0.908 & 0.653 & 1.018 & -0.499 & -0.245 & 0.869 & 0.702 & 0.121 & -0.05 & 0.708 & .683 \\
\hline$(0.965)$ & $(0.676)$ & $(0.369)$ & $(0.518)$ & $(0.314)$ & $(0.621)$ & $(0.807)$ & $(0.39)$ & $(0.486)$ & & & & \\
\hline \multicolumn{13}{|c|}{ Semi log } \\
\hline 2.568 & 0.499 & -0.189 & 0.533 & -0.053 & -1.055 & -0.061 & 0.378 & 0.155 & 0.114 & \multirow[t]{2}{*}{-0.059} & 0.661 & .722 \\
\hline$(0.014)$ & $(0.62)$ & $(0.851)$ & $(0.597)$ & $(0.958)$ & $(0.298)$ & $(0.952)$ & $(0.707)$ & \multicolumn{2}{|l|}{$(0.155)$} & & & \\
\hline \multicolumn{13}{|c|}{ Double log } \\
\hline 0.18 & 0.082 & -0.374 & 0.318 & $2.832^{*}$ & $-2.009^{\star}$ & -0.302 & 0.737 & $2.677^{*}$ & 0.175 & 0.014 & 2.09 & .039 \\
\hline$(0.858)$ & $(0.935)$ & $(0.711)$ & $(0.752)$ & $(0.04)$ & $(0.041)$ & $(0.764)$ & $(0.466)$ & $(0.05)$ & & & & \\
\hline
\end{tabular}

Source: Analysis from field data.

Table 3: Regression result on the total value of production

for every percentage increase in quantity of lime at a given level of other variable inputs, will reduce total value of production by $2.01 \%$. This could be as a result of over liming that can lead to water acidity [17]. Sex (X8) showed a positive relationship with the total value of production, this could be said that male farmers will have a higher labour productivity than female farmers, if all other variables are held constant.

\section{Limitation of the study}

Due to the problem of poor farm record keeping, the farmers could not give accurate record of their production and sales as most of the information obtained were recalled from memories [18]. Thus, the production and income data obtained might have been under-reported in this study.

\section{Conclusion and Recommendation}

The result of this study showed that fish farming in Saki-East Local Government Area is highly feasible and profitable. The Benefit-Cost Ratio recorded a good value of 1.9 and the Return on Investment also recorded a good value of 0.888 indicating a return of about 88 kobo should be expected on every N1 spent in the enterprise. The result also reflected that age and level of education of the fish farmers have positive relationship with the farmers output, indicating a positive increase with a unit increase in the factors. It can therefore be recommended from the study that government and farm friendly institutions should support the fish farmers in Saki-East LGA in term of more inputs supply and also educating the farmers on the need to form cooperative societies as to attract any government intervention opportunities, this is believed will help the farmers increase their profit margin in the study area and also would help the teaming unemployed youths (including graduates) to develop more interests in agriculture, especially aquaculture.

\section{References}

1. Fagade SO (1992) Production, Utilization and Marketing in fisheries; Status and opportunities. $20^{\text {th }}$ Annual Conference of FISON, Abeokuta, Nigeria.

2. Anthonio OR, Akinwumi JA (1991) Supply and Distribution of Fish in Ibadan Nigeria. Geog J 14: 16

3. FAO (1996) Fisheries Technical Paper, Rome

4. Adekoya BB (1993) Fueling in Crisis. Fish Network: a quarterly Publication of the Fisheries Society of Nigeria

5. Ahmed M, Bimpao MP, Gupta MV (1996) Economics of Tilapia Aquaculture in small Water bodies in Bangladesh.

6. Adekoya BB (2001) Enhancing the income generating capacity of cooperative societies and individuals in Ogun and Lagos States.

7. Borgese EM (1977) Sea Farm: The Story of Aquaculture. Henry N. Abrams Inc, New York.

8. Delgado LD, Wanda M, Rosegrant MW, Meier S (2003) Fish Outlook to 2020 International Food policy Research Institute, Washington.

9. FAO (1991) Fish for food and Employment, Food and Agricultural Organization, Rome.

10. FAO (2007) Aquaculture only way to meet global demand for fish-UN agency, FAO Bulletin.

11. Gertjan DE G, Johannes J (1996) Handbook on the artificial reproduction and Pond rearing of the African Catfish Clarias gariepinus in Sub-Saharan African Godwin Etuk (2005).

12. Igene (1991) Food Science and Technology in Nigeria Agriculture and Industria Development. Agricultural Science Tech.

13. Igene JO (1997) Food Production and Nutrition in Nigeria. Proceedings of the National Workshop of Nigeria's Position at the World Food Summit, Abuja.

14. Olagunju FI, Adesiyan IO, Ezekiel AA (2004) Economc viability of Fish farming in Oyo State, Nigeria. J. Hum Ecol 21: 121-124.

15. Othman MF, Sadek SS (2004) Industrial Fish Feed Production Development in Egypt. National Consultation on Fish Nutrition Research and Feed Technology, Egypt.

16. Sadek S, Osman MF, Mezayen A (2006) Aquaculture in Egypt, A fragile Colossus? . International Conference and Exhibition, Firenze Florence, Italy.

17. Sayyad Ruma (2008) 700,000 tonnes: The weight of Nigeria's slump.

18. Ngazy ZM (2004) Appraising Aquaculture: "The ZALA Park Fish Cultivation and Makoba Integrated Mariculture Pond System". State University of Zanzibar Tanzania. 